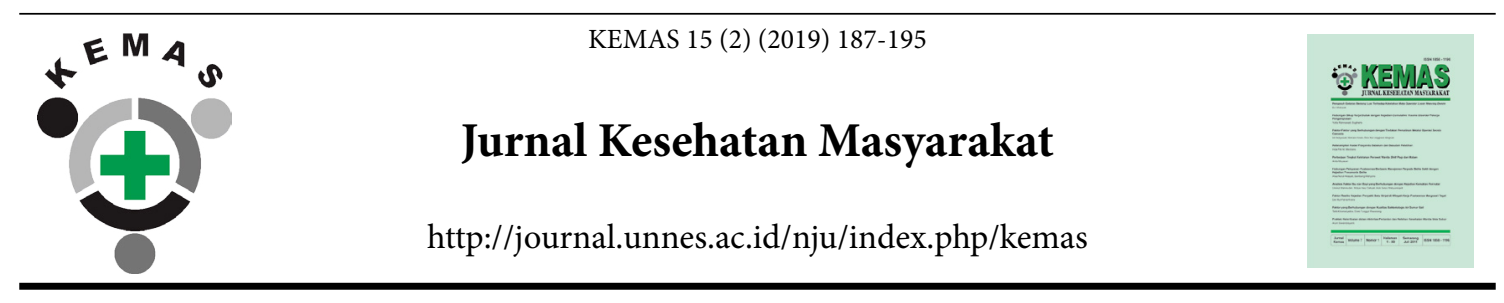

\title{
Stunting Intervension Strategy Based on Community Empowerment
}

\author{
Intan Fitri Meutia ${ }^{\bowtie}$, Devi Yulianti \\ Public Administration Department, Social and Political Sciences Faculty, Universitas Lampung
}

\section{Article Info \\ Article History: \\ Submitted May 2019 \\ Accepted July 2019 \\ Published November 2019 \\ Keywords: \\ Stunting, \\ Intervension Strategy, \\ Community Empowerment \\ DOI \\ https://doi.org/10.15294/ \\ kemas.v15i2.19049}

\begin{abstract}
The problem of stunting is still spread in various parts of the world including Indonesia which is a developing country with diverse community conditions. Lampung Province which is one of the regions with a high prevalence of stunting. This research is about the strategy intervention of stunting cases in Lampung Province through Asah, Asih and Asuh programs based on community empowerment. The focus of this research is on the stunting intervention strategy through Asah, Asih and Asuh program to the community. The research approach used descriptive qualitative type. The data analysis techniques used data reduction, data display and conclusion. There were some informants for this research such as the Head of the family and nutrition health section, Head of the Program and Data Evaluation Division, Head of the Health Services and Stakeholders Division. They were the keys informants. We picked ten to be interviewed. We decided to use purposive sampling to decide the informants. This study showed that the stunting intervension strategy was still weak because of some reasons such as 1). The program has not yet been performed on specific nutrition interventions from Lampung Provincial Health, 2). The human resources indicators have less ability in carrying out the Asah, Asih and Asuh programs and decision makers in formulating legislation for reducing stunting cases and 3). There is the cooperation among stakeholders to accelerate nutrition improvement activities in handling stunting.
\end{abstract}

\section{Introduction}

The main objective of national development is to improve the quality of human resources carried out sustainably in accordance with the concept of Sustainable Development Goals (SDGs), (Rukmana et al., 2016). The efforts acording to Pormes et al., (2018) can improve the quality of human resources began with the main concern in the process of child development from conception to young adulthood. During this growth period, fulfilling the basic needs of children such as care and nutritious food provided with love can form healthy, intelligent and productive human resources, (Tontisirin et al., 2002) and to achieve this objective in a development context requires an adequate supply, access and consumption of a variety of foods. Diets in developing countries generally lack many nutrients, including energy (inadequate amounts of food. Nutritional problems are a public health problem that can not only be overcome through medical approaches and health services, (Tontisirin et al., 2002)and to achieve this objective in a development context requires an adequate supply, access and consumption of a variety of foods. Diets in developing countries generally lack many nutrients, including energy (inadequate amounts of food. Under nutrition is a syndrome of poverty that is closely related to food security issues at the household level and involves aspects of knowledge and behaviors that do not support a healthy lifestyle (Wahyuni, 2018). 
Community nutrition conditions will affect the level of health and life expectancy which is one of the main elements in determining the success of development. Nutritional handling is closely related to a nation's strategy in creating healthy, intelligent and productive human resources, (Azwar et al., 2004). Efforts must be made in improving quality of human resources starting with the way to take care the growth of children as part of a family with good nutrition and parenting, (Dominguez-Salas et al., 2016). With a healthy environment, the presence of infectious diseases or other community diseases can be avoided. At the community level, factors such as hygienic environment, family health, care for children and primary health care are crucial in shaping children who are malnourished (Saragih, 2010). The success of national development sought by the government and society is very much determined by human resources. There are some indicators to form a quality human resources (Pelletier et al., 2013) such as strong physical, excellent health, and mastering science and technology (WHO, 2006).

In the Regulation of the Minister of Health of Republic Indonesia Number 23 Year 2014 concerning Efforts to Improve Nutrition stated that the improvement in the degree of public health needs to be carried out efforts to improve individual nutrition and community nutrition in the entire life cycle from the womb to the elderly with priority to the nutrition vulnerable group; also that efforts to improve nutrition were carried out based on guidelines that had been listed in various regulations that were not yet regulatory, (Atmarita et al., 2009). On the macro level, it requires firmness of policies, strategies, regulations, and crosssectoral coordination from the government and all stakeholders to ensure important points such as community empowerment, poverty alleviation, food security, and education that indirectly will change improper culture and paradigms (Nur Jannah, 2019).

The indicator of Age and Weight is an interpretation of good nutrition and poor nutrition (Pelletier et al., 2013). Indicator of nutritional status based on Age and Weight index gives an indication of nutritional problems in general. This indicator does not provide an indication of nutritional problems that are chronic or acute because weight is positively correlated with age and height. A low of Age and Weight indicator can be caused by short (chronic nutrition problems) or is suffering from diarrhea or other infectious diseases (acute nutritional problems) (Rosha et al., 2016).

These nutritional problems correlate with stunting cases. The problem of stunting is still spread in various parts of the world including Indonesia which is a developing country with diverse community conditions. Lampung Province which is one of the regions with a high prevalence of stunting (Nair et al., 2015).

Public health problems are considered serious if the prevalence of malnutrition is between $20 \%-29 \%$ and is considered to be very high if $\geq 30 \%$ (WHO, 2010). Although Lampung Province is still below 20\%, this shows an increasing trend from 2015, 2016 and 2017. If it is not intervened it will approach high prevalence. The prevalence of malnutrition fluctuated from 2015, 2016 and 2017. There were 3 regencies/ cities that experienced a decline, namely Central Lampung $18 \%$ (2015) $15.9 \%$ (2016) and $14.2 \%$ (2017), Pesisir Barat $12.3 \%$ (2015) 9.1\% (2016) and 8.5\% (2017) and Metro 16.9\% (2015) $15.9 \%$ (2016) and $14 \%$ (2017).

The prevalence of malnutrition in the 0-59 month age group in the province at $19 \%$. This increased significantly by $5 \%$ from the previous year which was $14.0 \%$. Of the 15 regencies/cities, 12 regencies/cities have a prevalence of malnutrition that is above the SDG's target (15.5\%). The regency has reached the target, namely West Lampung (9.7\%), Pesisir Barat, Way Kanan and East Lampung (15.4\%). Furthermore, the main objectives of the 2015-1019 RPJMN for the Health sector include increasing the health and nutrition status of mothers and children, increased disease control and increased access and quality of basic health services and referrals. For the first target as mentioned above, increasing the health and nutrition status of mothers and children is a top priority. In the Sustainable Development Goals (SDGs), given the high number of cases of maternal and child 
deaths, including in Central Lampung. In 2016 cases of maternal mortality (MMR) in Central Lampung were 13/100 live births and 75/1000 live births decreased compared to 2015 at 18 / 100 and 98/1000. Although there has been a decline in cases, Central Lampung remains one of the target areas of the central government for the AKI-AKB Reduction Program.

The efforts that have been made by the government to reduce maternal, newborn, infant and toddler deaths. among others, through the Health Program, placement of village midwives, empowerment of families and communities by using the Maternal and Child Health Book (MCH Handbook) and Childbirth Planning and Complication Planning (P4K) Program, as well as the provision of Village Health Post facilities (Poskeskam). Then, Basic Emergency Neonatal Obstetric Services (PONED) at the Community Health Center and Comprehensive Emergency Obstetric Neonatal Service (PONEK) at the Hospital, also through the Asah, Asih and Asuh program, (Ni' Mah \& Nadhoroh, 2016).

These efforts are a form of Lampung Province government intervention strategy that supports the health of mothers, infants and toddlers. Lampung Provincial Health Office as a public institution actually provides excellent service in the health sector to support the national ideals to realize a healthy and empowered society. Modern organization needs strategy as the response to the environment. Strategic management is an advance decision about what an organization should do in the future. Effective strategic management is dynamic process involving the human, physical and financial resources in order to achieve the objectives. Strategic management should provide focus to the programs of the organization. The effectiveness of such approach must be measured and the people served in terms of performance (Steiss, 2003).

Previous studies on stunting cases include: 1). Peran Intervensi Gizi Spesifik dan Sensitif Dalam Perbaikan Masalah Gizi Balita Di Kota Bogor (Rosha et al., 2016). The results of this study indicate that specific nutritional interventions are underfive intervention (monitoring toddlers in posyandu, immunization, vitamin $\mathrm{A}$ and
PMT), maternal intervention (classes of pregnant women, pregnant mother PMT, nutrition and health seminars) and adolescent intervention (tablet supplement/blood program TTD). While sensitive nutrition interventions are environmental health (Friday or Clean Sunday program, making biopori or communal septictank), poverty interventions (provision of BLT, family hope and PNPM), and women's empowerment interventions (health and nutrition counseling, provision of seedlings for environmental use), 2). Analisis Kebijakan Penanggulangan Masalah Gizi di Kalimantan Timur, (Saragih, 2010b). The results of the study indicate the success of intervention in nutrition problems in East Kalimantan Province due to efforts to provide nutrition for the community through Posyandu and Puskesmas related to Village Development Planning as an indicator of rural community development, 3). Pendampingan Masyarakat Dalam Upaya Mencegah Terjadinya Stunting (Nur Jannah, 2019). The results of this study indicate that through the posyandu cadre team and nutrition school resulted in an increase in public awareness in understanding healthy lifestyles. This was marked by the activity of the Posyandu cadre team, and 4). Permasalahan Anak Pendek (Stunting) Dan Upaya Untuk Mencegah Terjadinya Stunting (Mitra, 2015) especially occurred indeveloping and poor countries. Stuntingcan increase the risk of morbidity and mortality, and suboptimal brain development so that delayed motor development and mental retardation. Stuntingis a form ofgrowth failuredue tothe accumulation of nutrientin sufficiency from the beginning of pregnancy until 24 months old. This situation is exacerbated by inadequate catch-up growth. In Indonesia, based of Basic Health Research, there was an increase of $36.8 \%$ stunted children in 2010 to $37.2 \%$ in 2013 . Over the past 20 years,handling the problem of stunting is very slow. Globally, the percentage of children who were stunteddec lined by only 0.6 percent per year since 1990 . WHO proposed a global target reduction in the incidence of stunting in children under five years old by $40 \%$ in 2025, but it was predictedonly $15-36$ countries that meetthose targets. The purpose of this article was examined the incidence of stunting 
reduction and interventions of the policy. Focus on movement to improve nutrition to target the first 1,000 days of life, in the global order it was called Scaling Up Nutrition (SUN). The results showed that the stunting control policy included the National Nutrition Awareness Movement in the First 1000 Days of Life through specific and sensitive interventions.

The difference between this research and previous studies is the concept of community empowerment in overcoming stunting cases. Community level mechanism such as participation and empowerment can contribute to support helath and nutrition (Feruglio \& Nisbett, 2018). Community development is emphasized not only for pregnant women or women but the wider community in an area. From the background and several previous studies on stunting, the research team in this article formulated research questions on how to overcome stunting cases in Lampung Province based on community empowerment through the implementation of the Asah, Asih and Asuh program. The purpose of this study was to analyze the intervention strategy of Lampung Provincial Health Office in overcoming stunting cases based on community empowerment. The results of the study was useful to provide information and input related to strategy interventions to reduce stunting cases in both Lampung Province and national level.

Method

This study used a qualitative approach with a descriptive type. According to Neuman (2014) that qualitative research with a natural background and a phenomenon occurs in society is summarized in the form of words and observed based on events in the field. This study used the technique of collecting observation data, documentation and interviews. Data analysis was done by preparing data, understanding data, representing the data, and making the interpretation (Creswell, 2009).

The location of this study was at the Lampung Provincial Health Office. There were some informants for this research such as the Head of the family and nutrition health section, Head of the Program and Data Evaluation Division, Head of the Health Services and Stakeholders Division. They were the keys informants. We picked ten to be interviewed.
We decided to use purposive sampling to decide the informants. The focus of this research was the stunting intervention strategy through the Asah Asih Asuh program based on community empowerment.

\section{Result and Discussion}

Lampung Province's Medium-Term Development Plan (RPJMD) for 2015-2019 has established the Lampung Province Vision namely "Lampung Maju and Sejahtera in 2019". There are 8 missions taken to achieve the intended vision, namely: 1). Increasing economic development and strengthening regional independence, 2). Improving infrastructure for economic development and social services, 3). Improving the quality of education, health, culture and tolerance of religious life, 4). Improving the quality of education and health, 5). Transformation of Lampung culture and strengthening tolerance of religious life, 6). Increasing the preservation of natural resources and sustainable quality of the environment, \& 7). Upholding the rule of law, building a democratic civilization and improving good governance and increasing the competence and professionalism of ASN.

Those five Missions of the Regional Medium-Term Development Plan (RPJMD), the health sector was included in the third mission, namely Improving the quality of education, health, culture and tolerance of religious life. Based on the Lampung Province RPJMD, the Strategic Plan of Lampung Province Health Office in 2015 - 2019 was prepared with the vision "A Healthy and Independent Lampung Community" which is a picture of Lampung society in the future through health development that is characterized by its inhabitants living in the environment and with healthy behavior, having the ability to reach quality and equitable health services, and having the highest degree of health so that they can compete at national and international levels. In order to achieve the vision of Lampung Provincial Health Office in 2015 - 2019, the Mission of Lampung Provincial Health Office in 2015 - 2019 was prepared as follows: 1). Ensuring Equitable, Quality and Affordable Health Efforts, 2). Ensuring Availability of Health Resources, 3). Enhancing Partnerships and Community Empowerment. 
1. Asah (the need for early mental stimulation)

The children need to be stimulated early to develop as early as possible the sensory, motor, emotional-social, speech, cognitive, independence, creativity, leadership, moral and spiritual abilities of children. Sharpening is stimulation given to fulfill the needs of sharpening (stimulation), includes efforts to stimulate both verbally and nonverbally. This process is the forerunner of the learning, education, and training processes provided as early and appropriate as possible.

The purpose of stimulation (sharpening) the early childhood stimulation is an activity to adequately stimulate a child's basic ability to grow and develop optimally according to the potential. Giving stimulation (sharpening) also needs to be given early, stimulation is given in accordance with the stages of the age of the child. The stimulation is the activity of stimulating and training the abilities of children from outside the child's environment (parents or caregivers).

\section{Asih (Emotional needs)}

Giving affection is important to create a sense of security (emotional security) with physical and psychological contact as early as possible with the mother. Children's needs for affection, attention and respect, new experiences, praise, and responsibility.

3. Asuh (Biomedic needs)

It is concerning the nutritional intake of children during the womb and afterwards, the need for shelter, proper and safe clothing, early health care in the form of immunization and early intervention will cause symptoms of the disease. The purpose of stimulation for toddlers aged $0-1$ years is so that they must know the source of sound and look for objects that are not visible, exercise sensitivity to touch, eyehand coordination and eye-ear. Whereas for toddlers aged 2-3 years the stimulation needed is to train to develop language skills, color, develop intelligence and imagination.

Stages of toddlers aged 3-6 years are developing abilities of differences and similarities, counting, and sports. Stimulation will make the nervous system function properly. The growth of the human brain reaches its peak when toddlers reach the age of five. In addition to stimulation and nutrition assistance, which is noless important is family support in optimizing stimulation in children. Giving stimulation and nutrition to children cannot be left entirely to caregivers or baby sitters. Parents must play an active role in fostering family togetherness and creating quality time with little time but best utilized. It can be applied in simple terms such as eating together. This opportunity can be used to introduce a variety of foods, names and colors to children, and teach eating skills. When a child drinks milk can be accompanied by reading a story book or watching television while slipping the message of the benefits of drinking milk for children. Try to accompany the child and chat while watching television. Encourage children to exercise or play to know the nature and environment at the weekend. Togetherness between parents and children is needed to establish communication in order to enable the provision of stimulation and proper nutrition for children. Stimulation needs or efforts to stimulate children to introduce new knowledge or skills are very important in improving children's intelligence. Stimulation in children can be started since the prospective baby is a fetus, because the fetus is not a passive creature. In the womb, the fetus can breathe, kick, squirm, move, swallow, suck the thumb, and others.

There are 4 aspects of the basic abilities of children who need to get stimulation, namely: gross movement ability, subtle movement ability, speech and language skills, as well as social skills (interacting) and independence.

There are three stages in national and regional strategies in carrying out the movement of the Asah, Asih and Asuh Program, namely:

\section{Implementation Strategy}

This stage explains and describes the strategies of the Central Government and the Regional Government in carrying out the Asah, Asih and Asuh program movements: 1). Increase cooperation capacity among stakeholders to accelerate evidence-based nutrition improvement activities, 2). Increase capacity to facilitate cooperation between stakeholders, 3). Increase the capacity to implement mutually beneficial cooperation among various stakeholders, 4). Increase capacity for monitoring and evaluating joint performance in order to achieve targets for improving 
nutrition, Increase capacity for identification by sharing experiences or related intervention models to improve understanding in achieving goals \& 5). Increase capacity for advocacy in the context of increasing political commitment and mobilizing resources and technical assistance. 2. Resource Mobilization Strategy

These strategy includes : a).Calculate budget requirements for nutrition improvement programs, b).Calculate the budget gap between current needs and availability, c).Prove that activities carried out in an integrated manner both in budgeting for specific nutrition interventions and sensitive nutrition interventions are more effective when compared separately, and d). Coordinate advocacy activities nationally and globally to reduce the budgeting gap and for resource mobilization, (Source : Policy and Strategy of Lampung Province Health Office).

The Central Government through the Regional Government in carrying out the Asah, Asih and Asuh program movements has principles and involvement, namely: a). Transparent: all stakeholders demonstrate the results of joint actions in a transparent and honest manner, b). Inclusive: through collaborative partnerships among stakeholders to improve interventions and desired outcome, c). Rightsbased: acts in line with the commitment to uphold justice and rights for all women, men and children, d). Willingness to negotiate: when conflict arises, it is jointly determined to resolve conflict and lead to a better direction, e).Shared responsibility: all stakeholders have a shared sense of responsibility in organizing activities collectively as evidence of shared commitment, f). Cost-effective: arranging several priorities based on evidence-based analysis and setting priorities that have the greatest leverage in achieving targets but with the most minimal funds and $\mathrm{g}$ ). Continuous communication: communication through sharing experiences routinely among stakeholders includes things that succeed and fail. (Source : Policy and Strategy of Lampung Province Health Office).

Emphasized the importance of partnerships with various parties or stakeholders to address nutritional problems. Nutrition improvement programs are not only the responsibility and carried out by the government, but also need to involve various stakeholders such as community institutions and the business parties.

These are the stakeholders of this program : 1). The Government has the role of initiator, facilitator, and motivator of Asah, Asih and Asuh Programs, which consist of development partners, community organizations, the business partners, 2). Development Partners strengthen national ownership and leadership, focus on results, adopt a multisectoral approach, focus on effectiveness, promote accountability and strengthen collaboration and inclusion, 3). Community Organizations The task of community organizations is to strengthen mobilization, advocacy, communication, research and analysis of policies and implementers at the community level to deal with malnutrition and 4).The business parties are in charge of product development, quality control, distribution, research, development of information technology, communication, promotion of behavior change for healthy living. Below is the data about the local goverment's startegy to implement Asah, Asih and Asuh program.

Poverty and the low level of education are seen as the root causes of society's shortcomings in stunting. Therefore these nutritional problems are closely related to the health of pregnant and lactating women, newborns and children under two years old. When calculated from the first day of pregnancy, the birth of a baby to a child aged two years, this period is the first 1000 days of human life. This period has been scientifically proven to be determines the quality of life. Therefore this period is called the golden and critical period as the research from Mitra (2015) especially occurred indeveloping and poor countries. Stuntingcan increase the risk of morbidity and mortality, and suboptimal brain development so that delayed motor development and mental retardation. Stuntingis a form ofgrowth failuredue tothe accumulation of nutrientin sufficiency from the beginning of pregnancy until 24 months old. This situation is exacerbated by inadequate catch-up growth. In Indonesia, based of Basic Health Research,there was an increase of $36.8 \%$ stunted children in 2010 to $37.2 \%$ in 2013. Over the past 20 years, handling the problem of 
Tabel 1. The Government's Short and Medium Strategy in Implementing Asah, Asih and Asuh Programs

\begin{tabular}{lll}
\hline No & Short Term (18 Months) & Medium Term (36 Months) \\
\hline 1 & Establish the Presidential Regulation on the & Mobilization of funding sources in APBN and \\
& Movement of Asah, Asih and Asuh Programs & $\begin{array}{l}\text { APBD, including PPP and CSR and international } \\
\text { development partners }\end{array}$
\end{tabular}

2 Compile Academic Manuscripts

Evaluate the achievement of goals, objectives and implementation of activities

3 Compile The Program Framework

Improve partnerships with development partners

4 Develop Program Planning Guidelines

Enhance partnerships with the business entities

5 Socialization of national and regional Asah, Asih and Asuh Programs

Improve partnerships with community institutions

6 Preparation of a monitoring and evaluation framework

Increase cooperation in the context of synchronizing planning and carrying out activities

$7 \quad$ Periodic National Task Force Meeting

Increase cooperation in the context of synchronizing planning and budget

8 Periodic Meeting of the Task Force Team

Replicate programs models that prove effective

9 Prepare regular reports on the progress of Advocacy to the legislature and

Asah, Asih and Asuh Program

Executive

Source : Lampung Province Health Office

stunting is very slow. Globally, the percentage of children who were stunteddec lined by only 0.6 percent per year since 1990 . WHO proposed a global target reduction in the incidence of stunting in children under five years old by $40 \%$ in 2025 , but it was predicted only $15-36$ countries that meetthose targets. The purpose of this article was examined the incidence of stunting reduction and interventions of the policy. Focus on movement to improve nutrition to target the first 1,000 days of life, in the global order it was called Scaling Up Nutrition (SUN. The research showed that the stunting control policy included the National Nutrition Awareness Movement in the First 1000 Days of Life through specific and sensitive interventions.

In the introduction section, we stated that Indonesia is a country that has stunting problems, where babies and pregnant women are being victims with nutritional problems. Nutritional problems that usually arise are malnutrition in infants and children under two years, the babies do not get breast milk because they are separated from their mothers, and the deterioration in the nutritional status of the community groups before the disaster is in a problematic condition. The babies who are $0-12$ months are the vulnerable group when having the experience in emergency situation, considering that this group of children is very vulnerable to sudden changes in food consumption and environmental conditions. Nutrition interventions for babies who are victims are done by giving breast milk. This menas nutritional problems could be solved by mother's participations to give the nutritions in many ways. These are the empowerment from 
community as the contents in Asah, Asih and Asuh Program.

Referring to the theory suggested by Thompson et al., (2007). It was the capability of the Asah, Asih and Asuh program in integrating and exploring resources within the organization to achieve the desired goals by Lampung Provincial Health Office, both human resources, the strengths and weaknesses of the Asah, Asih and Asuh program and also other stakeholder institutions. Capability is not created with just one source without the support of other resources. The capability is very important to be owned by Lampung Provincial Health Office, especially in carrying out the Asah, Asih and Asuh Program because these capabilities are identified as one of the main sources for generation and competitive development, uncertainty and environmental change are the reasons that the Lampung Provincial Health Service must have the capability to change and develop important prerequisites quickly to maintain a competitive advantage from Asah, Asih and Asuh Program.

Organizational capability is determined based on two approaches, namely the functional and the value chain approach. Functional approach determines organizational capabilities relative to the main functions of the company, such as marketing, distribution, finance and accounting, human resources, production and organization in general. Capability is an attribute of an organization that allows it to exploit the resources that exist in implementing the strategy. The main purpose of capability is to increase the productivity of other resources. The intended resources are the attributes of financial, physical, individual, and organizational capital which are the basic capital of Lampung Provincial Health Office.

\section{Conclusion}

Based on the results of the study, it is concluded that the intervensions strategies in reducing stunting in Lampung Province are still weak because of some reasons such as 1). the program has not yet performed specific nutrition interventions from Lampung Provincial Health, 2). The human resources indicator have not increased the responsibility of human resources in carrying out the Asah, Asih and Asuh programs and decision makers in formulating legislation in reducing stunting cases and 3). There has not been an increase in cooperation capacity among stakeholders to accelerate nutrition improvement activities in handling stunting.

\section{References}

Atmarita, T, S., Abas, B, J., \& Robert, T., 2009. The Emergence of Combined Stunting and Obesity as a Nutritional Threat To Child Development in Indonesia. Gizi Indonesia, 32(2): 90-104.

Azwar, A., Dirjen, M., \& Kesmas, B., 2004. Kecenderungan Masalah Gzi dan Tantangan di Masa Datang.

Creswell, J. W., 2009. John W. Creswell-Research Design_ Qualitative, Quantitative, and Mixed Methods Approaches ...

Dominguez-Salas, P., Alarcón, P., Häsler, B., Dohoo, I. R., Colverson, K., Kimani-Murage, E. W., ... Grace, D., 2016. Nutritional Characterisation of Low-income Households of Nairobi: Socioeconomic, Livestock and Gender Considerations and Predictors of Malnutrition from a Cross-sectional Survey. BMC Nutrition, 2(1): 47.

Feruglio, F., \& Nisbett, N., 2018. The Challenges of Institutionalizing Community-level Social Accountability Mechanisms for Health and Nutrition: a Qualitative Study in Odisha, India. BMC Health Services Research, 18(1): 788.

Mitra., 2015. Permasalahan Anak Pendek (Stunting) dan Intervensi untuk Mencegah Terjadinya Stunting (Suatu Kajian Kepustakaan). Jurnal Kesehatan Komunitas, 2(6): 254-261.

Nair, N., Tripathy, P., Sachdev, H. S., Bhattacharyya, S., Gope, R., Gagrai, S., ... Prost, A., 2015. Participatory Women's Groups and Counselling Through Home Visits to Improve Child Growth in Rural Eastern India: Protocol for a Cluster Randomised Controlled Trial. BMC Public Health, 15(1): 384.

Neuman, W. L., 2014. Social Research Methods: Qualitative and Quantitative Approaces (7th ed.).

Ni' Mah, K., \& Nadhoroh, S., R., 2016. Faktor yang Berhubungan dengan Kejadian Stunting pada Balita. Media Gizi Indonesia, 10(1): 13-19.

Nur, J., C., 2019. Pendampingan Masyarakat dalam Upaya Mencegah Terjadinya Stunting pada Balita di Desa Karangturi Kecamatan Glagah Kabupaten Lamongan Melalui Tim Kader Posyandu (Universitas Islam Negeri Sunan 
Ampel Surabaya).

Pelletier, D., Haider, R., Hajeebhoy, N., Mangasaryan, N., Mwadime, R., \& Sarkar, S., 2013. The Principles and Practices of Nutrition Advocacy: Evidence, Experience and the Way Forward for Stunting Reduction. Maternal \& Child Nutrition, 9: 83-100.

Pormes, W. E., Rompas, S., Ismanto, A. Y., \& Ismanto, A. Y., 2018. Hubungan Pengetahuan Orang Tua tentang Gizi dengan Stunting pada Anak Usia 4-5 Tahun di TK Malaekat Pelindung Manado. Jurnal Keperawatan, 2(2).

Rosha, C. B., Sari, K., SP Yunita, I., Amaliah, N., \& Utami, N., 2016. Peran Intervensi Gizi Spesifik dan Sensitif dalam Perbaikan Masalah Gizi Balita di Kota Bogor. Buletin Penelitian Kesehatan, 44(2): 127-138.

Rosha, C. B., Sari Kencana, Yunita, I., Amaliah, N., \& Utami, N., 2016. Peran Intervensi Gizi Spesifik dan Sensitif dalam Perbaikan Masalah Gizi Balita di Kota Bogor. Buletin Penelitian Kesehatan, 44(2): 127-138.

Rukmana, E., Briawan, D., Ekayanti, I., \& Ekayanti, I., 2016. Faktor Risiko Stunting pada Anak Usia 6-24 Bulan di Kota Bogor. Media Kesehatan Masyarakat Indonesia, 12(3): 192-199.

Saragih, B., 2010. Analisis Kebijakan Penanganan Masalah Gizi di Kalimantan Timur
Berdasarkan Pengalaman Berbagai Negara. Jurnal Borneo Administrator, 6(3): 1-20.

Saragih, B., (2010b).

Steiss, A., W., 2003. Strategic Management for Public and Nonprofit Organizations (1st ed.; J. Rabin, Ed.).

Thompson, A. A., Strickland, A. J., \& Gamble, J, E., 2007. Crafting and Executing Strategy (17th ed.).

Tontisirin, K., Nantel, G., \& Bhattacharjee, L., 2002. Food-based Strategies to Meet the Challenges of Micronutrient Malnutrition in the Developing World. Proceedings of the Nutrition Society, 61(02): 243-250.

Wahyuni, S., 2018. Hubungan Status Gizi dengan Prestasi Belajar Siswa di SDN 3 Buntalan Klaten Tengah. Jurnal Riset Kebidanan Indonesia, 1(2): 76-81.

WHO., 2006. The World Health Report 2006: Working Together for Health.

WHO., 2010. WHO Report On Neglected Tropical Diseases 2010: Working To Overcome The Global Impact Of Neglected Tropical Diseases. 